\title{
Efektivitas Poster Pemberian Nutrisi Anak Terhadap Pengetahuan Orangtua Tentang Pemberian Nutrisi Dalam Pencegahan Stunting Di TK Bina Anaprasa Nurul Jadid
}

\section{Zainal Munir', Abd. Rohman ${ }^{2}$, Fina Zaiana Putri ${ }^{3}$, Inayah Riski Wulandari ${ }^{4}$}

1. Fakultas Kesehatan Universitas Nurul Jadid, Email: zainalmunirnj@gmail.com

2. Fakultas Kesehatan Universitas Nurul Jadid, Email: Abdrohmanpuro@gmail.com

3. Fakultas Kesehatan Universitas Nurul Jadid, Email: finazaiana08@gmail.com

4. Fakultas Kesehatan Universitas Nurul Jadid, Email: inayahrisky17@gmail.com

\section{Abstract}

The increasing number of stunting in Indonesia has crossed the WHO limit and has become a national issue that the incidence of stunting leads to unmet nutritional needs starting from the fetus to the age of toddlers, toddlers to toddlers. The purpose of the study was to find out the effectiveness of posters for giving children nutrition to parents' knowledge about nutrition in preventing stunting. This research is an intervention research by providing nutrition and stunting health education with 1 group pre-post test with pictorial media in the form of posters. The technique used is total sampling, namely all parents who have children from Bina Anaprasa Kindergarten. Data was collected by using a paired T-test approach through a pre-post test. The average result obtained is an average difference with a $\mathrm{p}$ value of 0.031 , which means 
that there is an increase in knowledge of parents after being given nutrition education interventions in preventing stunting.

Keywords: Posters, Nutrition, Stunting

\section{Abstrak}

Meningkatnya angka kejadaian stunting di Indonesia melewati batas dari WHO dan menjadai permasalahan issue nasional bahwa kejadian stunting bermuara dari kebutuhan nutrisi yang tidak terpenuhi dimulai dari masa janin hingga usia baduta, batita sampai balita. Tujuan dari penelitian inginmengetahui efektifitas poster pemebrian nutrisi anak terhadap pengetahuan orangtua tentang pemebrian nutrisi dalam pencegahan stunting. Penelitian ini merupakan penelitian intervensi dengan memberikan pendidikan kesehatan nutrisi dan stunting dengan 1 kelompok pre-post test dengan media bergambar berupa poster. Tehnik yang digunakan total sampling yaitu seluruh orangtua yang punya anak sekolah TK Bina Anaprasa. Pengumpulan data dilakukan dengan pendekatan paired T-test melalui prepost test. Hasil rata-rata yang didapatkan perbedaan rata-rata dengan $p$ value 0,031 yang artinya terdapat peningkatan pengetahuan pada orangtua setelah diberikan intervensi edukasi pemberian nutrisi dalam pencegahan stunting.

Kata kunci: Poster, Pemberian Nutrisi, Stunting 
Zainal Munir: Pencegahan Stunting 


\section{PENDAHULUAN}

Stunting adalah tinggi badan seseorang jauh lebih pendek dibandingkan tinggi badan seusia. Stunting dikenal dengan istilah kerdil atau pendek dibandingkan terjadi sejak dalam kandungan sampai awal kehidupan anak yaitu 1000 Hari Pertama Kehidupan (HPK). Stunting bisa diketahui bila anak telah berusia 2 tahun dengan mengukur tinggi badan, lalu dibandingkan dengan standar dan hasil pengukuran berada pada kisaran di bawah normal bu(Kemenkes, 2018).

Prevalensi

Stunting

menjadi masalah

kesehatan masyarakat jika prevalensi $20 \%$ atau lebih (WHO 2015, n.d.) Di Indonesia stunting fluktuatif mencapai 37,2 $\%$, sempat turun pada tahun 2013 menjadi 30,8\% (Kemenkes, 2018). Pada tahun 2016 sebesar $27,5 \%$ namun meningkat tahun 2017 menjadi $29,6 \%$ dan tahun 2018 menjadi 30,8\% (Kemenkes, 2018). Prevalensi di Indonesia juga tergolong tinggi dibanding Myanmar
(35\%), Malaysia (17\%), Thailand (16\%) dan Singapura (4\%). Indonesia termasuk dalam 17 negara diantara 117 negara, yang mempunyai tiga masalah gizi yaitu stunting, wasting, dan Overweight pada balita (Picanyol, 2014). Stunting di Indonesia saat ini semakin tinggi, seperti data yang dikeluarkan oleh Kemenkes RI pada tahun 2005 - 2017 Prevalensi stunting di Indonesia mencapai 36,4\%, lebih dari sepertiga atau 8,8 juta balita mengalami stunting (Jakarta 12950, 2018).

Angka stunting itu terus meningkat khususnya di Jawa Timur hingga tahun 2018. Menurut data dari Riset Kesehatan Dasar (Riskesdas) Prevalensi stunting di Jawa Timur mencapai 32,81 (Surabaya, 2018). Hal ini ditandai dengan meningkatnya prevalensi stunting di setiap Kabupaten-Kabupaten yang ada di jawa timur, salah satunya di Kabupaten Probolinggo. Saat ini prevalensi stunting 
yang ada di Probolinggo saat ini mencapai 39,9 (2019. Probolinggo, 2019). Kasus bayi stunting tidak boleh dianggap remeh, karena balita yang terkena stunting akan mengalami tingkat kecerdasan yang tidak setara dengan balita yang normal. Selain itu, balita akan rentan terkena penyakit sehingga sangat beresiko terhadap menurunnya tingkat produktivitas di masa depan (Jakarta, 2017). Oleh Karena itu perlu ada penanganan khusus agar kasus stunting semakin menurun JKAKJ, 2018).

Penanganan stunting yang sedang diupayakan oleh pemerintahan Kabupaten Probolinggo salah satunya yaitu bekerja sama dengan GAIN (Global Alliance for Improved Nutrition) dari Kementrian Kesehatan RI menggunakan program yang sudah ada sebelumnya melalui metode teknik Emo Demo (Emotional Demonstration) guna untuk meningkatkan kesehatan masyarakat, khususnya masyarakat yang memiliki kasus stunting (2020.
Probolinggo, 2020). Selain itu, pemerintah berinisiatif untuk mengajak masyarakat serta perguruan tinggi untuk ikut berperan (Udayana Mengabdi, vol. 15, no. 01, n.d.) Berbagai penelitian penyebab stunting diantaranya kekurangan gizi kronis sejak dalam kandungan hingga masa awal anak lahir, kurang Energi Kronik (KEK) pada ibu hamil memiliki proporsi $38,5 \%$ dan menurun pada tahun 2018 menjadi 17,3\% (Kementerian Kesehatan RI. (2018)., n.d.) KEK ini berkaitan dengan kejadian anemia ibu hamil. Diperkirakan 41,8\% ibu hamil diseluruh dunia mengalami anemia. Sedangkan di Indonesia anemia ibu hamil pada tahun 2013 sebesar 37,1\% dan meningkat pada tahun 2018 menjadi 48,9\% (Kementerian Kesehatan RI. (2018)., n.d.)

Anemia ibu hamil terutama disebabkan defisiensi besi. Defisiensi besi berkaitan dengan pemberian Tablet Tambah Darah (TTD) selama hamil. Cakupan konsumsi TTD 
hanya 33,2\%. Hal ini dapat mempengaruhi tumbuh kembang janin sehingga mengakibatkan kelahiran prematur dan BBLR. Kejadian stunting berhubungan dengan BBLR (Media Gizi Pangan, n.d.) Prevalensi BBLR tahun 2015 sebesar $10,2 \%$. Selain itu panjang badan lahir < $48 \mathrm{~cm}$ juga memiliki prevalensi stunting sebesar 20,2\%. Stunting sebagai indikator kesejahteraan anak dan refleksi dari kesenjangan sosial (Branca, n.d.) Beberapa penelitian menemukan faktor yang berhubungan dengan stunting diantaranya berat lahir, panjang badan lahir, riwayat ASI Ekslusif, pendapatan keluarga, pendidikan ibu, dan pengetahuan gizi (Media Gizi Indonesia, 1, n.d.)

Faktor tinggal didaerah perdesaan, jumlah anak dibawah 5 tahun dalam rumah tangga, sanitasi lingkungan berkaitan erat dengan kejadian stunting, ASI meningkatkan kekebalan tubuh bayi dan menurunkan risiko infeksi. Pemberian ASI dilakukan sejak dini dengan mendapat Inisiasi
Menyusu Dini (IMD) dan ASI Ekslusif sampai bayi berusia 6 bulan tanpa adanya tambahan makanan. Cakupan IMD 2017 adalah 73,06\% (Kemenkes, 2018)Cakupan ASI Ekslusif di tahun 2015 hanya sebesar 41,9\% (Kementerian Kesehatan RI. (2018)., n.d.)

Terdapat hubungan Pemberian ASI Ekslusif pada bayi dengan pertumbuhan bayi di Wilayah Kerja Puskesmas Simpang Baru Pekanbaru, kejadian stunting banyak terjadi pada anak yang tidak diberi ASI Ekslusif karena memiliki resiko 6,54 kali dibandingkan ASI Ekslusif, penelitian lain menemukan resiko stunting pada anak yang tidak diberikan ASI Ekslusif sebesar 6,9 kali (Paudel, R., Pradhan, B., Wagle, R. R., Pahari, D. P., \& Onta, n.d.) Tingginya kejadian stunting dipengaruhi pendapatan dan pendidikan orang tua. Keluarga dengan pendapatan tinggi lebih mudah memperoleh akses pendidikan dan kesehatan sehingga status gizi anak dapat lebih baik 
(Bishwakarma, R., \& Vanneman, 2011)

Beberapa

faktor penyebab stunting terdiri dari; 1) Praktek pengasuhan yang kurang baik, 2) Masih terbatasnya layanan kesehatan $t$ ermasuk layanan ANC Ante Natal Care, Post Natal Care dan Pembelajaran dini yang berkualitas, 3) Masih kurangnya akses keluarga ke makanan bergizi, dan 4) Kurangnya akses air bersih dan sanitasi. Faktor ibu dan pola asuh yang kurang baik seperti perilaku dan praktik pemberian makan kepada anak berhubungan dengan pola konsumsi ibu dimulai dari saat hamil, kelahiran anak hingga baduta. Kondisi konsumsi makanan ibu hamil dan balita (2016 - 2017) berdasarkan hasil, terdapat 1 dari 5 ibu hamil kurang gizi, 7 dari $10 \mathrm{ibu}$ hamil kurang kalori dan protein, 7 dari 10 balita kurang kalori serta 5 dari 10 balita kurang protein. Penanganan stunting sesuai sasaran merupakan harapan bersama. Upaya penurunan prevalensi stunting dilakukan dengan intervensi 1000 HPK, menyelenggarakan

konseling IMD dan ASI Ekslusif (Menteri Kesehatan RI. (2016), n.d.) Stunting

bisa

diintervensi dengan cara: 1) Mendapat TTD minimal 90 tablet selama hamil, 2) Pemberian makanan tambahan ibu hamil, 3) Pemenuhan gizi, 4) Persalinan dengan dokter atau bidan yang ahli, 5) IMD, 6) Berikan ASI Ekslusif (0-6 bulan), 7) Berikan Makanan Pendamping ASI ( 6 bulan 2 tahun), 8) Berikan Imunisasi dasar lengkap dan Vitamin A, 9) Pantau pertumbuhan Baduta di Posyandu terdekat, dan 10) Lakukan PHBS (Kementerian Desa Transmigrasi

Pembangunan Daerah Tertinggal dan. (2017), n.d.).

Berdasarkan penelitian pada 2100 ibu dengan baduta dan 1050 Bumil di 6 provinsi didapatkan data bahwa saat hamil, $43 \%$ ibu makan < 3x/hari dan $35 \%$ ibu hamil mengkonsumsi kurang dari jumlah yang biasa dimakan, banyak Ibu hamil menghindari pangan hewani karena kuatir 
tidak bersih / amis dan sulit melahirkan, $61 \%$ anak hanya makan pangan pokok dan sayur, $40 \%$ anak makan $<3 \times /$ hari dan tidak biasa sarapan. Intervensi stunting yang menentukan yaitu mempersiapkan calon ibu, memberikan pelayanan ANC, dan memastikan persalinan dilakukan di fasilitas pelayanan kesehatan. Disamping itu, pemberian ASI Ekslusif, IMD serta pemantauan tumbuh kembang dilakukan terus menerus oleh tenaga kesehatan pada 1000 (Kementerian Kesehatan RI. (2018)., n.d.). Penelitian yang dilakukan sebelumnya dengan judul faktor-faktor yang berhubungan dengan peningkatan kasus stunting di kabupaten probolinggo, bahwa gizi ibu saat hamil, pola asuh, status ekonomi (pendapatn keluarga) menjadi faktor yang menyebabkan meningkatnya kasus stunting di Kabupaten Probolinggo (Munir et al., 2021)

Kejadian stunting berkaitan erat dengan berat badan lahir dan pemberian ASI di Puskesmas Lima Puluh Kota Pekanbaru (Fitri, n.d.) BBLR memiliki resiko stunting 4,47 kali lebih besar dibandingkan berat lahir normal (Paudel, R., Pradhan, B., Wagle, R. R., Pahari, D. P., \& Onta, n.d.) Bayi BBLR akan lebih rentan terhadap pengaruh lingkungan yang kurang baik dimasa mendatang . Disamping itu dapat berdampak negatif dari stunting seperti penurunan intelektual anak, rentan terhadap penyakit tidak menular, penurunan produktifitas sehingga dapat menyebabkan kemiskinan (Media Gizi Indonesia, 1, n.d.) Metode KIE melalui poster menstimulus dan meningkatkan daya ingat ibu melalui visual sehingga pembelajaran mengenai stunting dengan mudah dipahami. Pilihan yang tepat dalam penanganan stunting untuk memperbaiki diet selama 1000 HPK meliputi diversifikasi diet dan peningkatan asupan gizi pada masa prenatal, postnatal hingga bayi berusia 2 tahun. Strategi 
ini berdampak positif pada pertumbuhan bayi (Dewey, K. G. (2016, 2016), dan menurunkan angka prevalensi stunting (Kurnia Illahi, n.d.) Pemantauan Status Gizi (PSG) 2017 menunjukkan prevalensi stunting berkurang sejalan dengan program pemerintah dalam penanggulangan

berdasarkan penyebab stunting (Kementerian Kesehatan RI. (2018)., n.d.)

Program yang tepat dengan mempertimbangkan faktor penentu dan penyebab kejadian stunting serta diseminasi ilmu berkaitan nutrisi (García Cruz, L. M., González Azpeitia, G., Reyes Súarez, D., Santana Rodríguez, A., Loro Ferrer, J. F., \& Serra-Majem, 2017). Strategi nasional percepatan pencegahan stunting disusun melalui proses penilaian dan diagnosis pencegahan stunting untuk memastikan agar semua sumber daya diarahkan dan dialokasikan untuk mendukung membiayai kegiatan prioritas terutama untuk meningkatkan cakupan dan kualitas pelayanan gizi pada kelompok ibu hamil dan anak berusia 023 bulan atau rumah tangga 1000 (Kementerian Koordinator Bidang Pembangunan Manusia dan Kebudayaan. (2018), n.d.) Salah satu upaya yang dapat kita lakukan adalah memberikan edukasi tentang pencegahan stunting pada ibu hamil dengan pola diet 1000 HPK.

\section{METODE}

Jenis penelitian ini adalah Quasy Eksperimen one group Pre Post Test dengan rancangan PreTest - Post Test pada kelompok Pre dan kelompok Eksperimen. Pada kelompok pre diberikan kuesioner untuk mengetahui pengetahuan orangtua tentang pemberian Nutrisi pada anak, setelah mendapatkan data Pre maka kelompok Post diberikan perlakuan dengan pemberian poster cara pemberian Nutrisi pada Anak. Populasi penelitian adalah seluruh orangtua yang anaknya disekolahkan di TK Bina Anaprasa Nurul Jadid. 
Penelitian dilakukan setelah mendapatkan izin dari pihak TK Bina Anaprasa Nurul Jadid.

Teknik pengambilan sampel adalah total sampling. Seluruh orangtua yang anaknya disekolahkan di TK Bina Anaprasa Nurul Jadid dijadikan sampel penelitian yaitu sebanyak 26 orang. Sebelum diberikan pendidikan kesehatan dan poster cara pemberian Nutrisi Anak, dilakukan pengukuran tingkat pengetahuan ibu kedua kelompok (pre-test). Kemudian dilakukan intervensi pada kelompok ekperimen sebanyak 3 kali yang terdiri dari Pendidikan kesehatan dan pemberian poster yang dibawa pulang. Pada Hari ke IV diberikan kembali kuesioner untuk mengetahui pemahaman ibu setelah diberikan pendidikan kesehatan (post-test). Selanjutnya dilakukan analisis Uji $\mathrm{T}$ Independent untuk menilai perbedaan hasil Pre-Test dan Post-Test Pada kelompok.

\section{HASIL PENELITIAN}

Hasil

analisis

univariat pada karakteristik responden berdasarkan jenis kelamin, tempat tinggal, jenis kelamin anak, Umur Orangtua, umur anak, hubungan dengan anak, jumlah anak, Pendidikan, Pendapatan, Pekerjaan orangtua tentang pemberian nutrisi dalam pencegahan stunting di TK Bina Anaprasa Nurul Jadid.

Table

$1:$

Karakteristik responden berdasarkan jenis kelamin, tempat tinggal, jenis kelamin anak, Umur Orangtua, umur anak, hubungan dengan anak, jumlah anak, Pendidikan, Pendapatan, Pekerjaan orangtua

\begin{tabular}{|c|c|c|c|}
\hline $\begin{array}{l}\mathrm{N} \\
\mathrm{O}\end{array}$ & Varibel & $\begin{array}{c}\text { Juml } \\
\text { ah }\end{array}$ & $\begin{array}{c}\text { Frekue } \\
\text { nsi }\end{array}$ \\
\hline \multirow[t]{3}{*}{1} & $\begin{array}{c}\text { Jenis Kelamin } \\
\text { Orangtua }\end{array}$ & & \\
\hline & $\begin{array}{c}\text { Perempua } \\
\mathrm{n}\end{array}$ & 26 & $100 \%$ \\
\hline & laki-Laki & 0 & $0 \%$ \\
\hline \multirow[t]{3}{*}{2} & $\begin{array}{l}\text { Tempat } \\
\text { Tinggal }\end{array}$ & & \\
\hline & $\begin{array}{cc}\text { Pegunung } \\
\text { an }\end{array}$ & 0 & $0 \%$ \\
\hline & pesisir & 26 & $100 \%$ \\
\hline \multirow[t]{3}{*}{3} & $\begin{array}{c}\text { Jenis kelamin } \\
\text { anak }\end{array}$ & & \\
\hline & $\begin{array}{cc}\text { Perempua } \\
\mathrm{n}\end{array}$ & 23 & $88 \%$ \\
\hline & 2 laki-Laki & 3 & $12 \%$ \\
\hline
\end{tabular}


Zainal Munir: Pencegahan Stunting

\begin{tabular}{|c|c|c|c|c|}
\hline \multirow[t]{5}{*}{4} & \multicolumn{2}{|c|}{$\begin{array}{c}\text { Umur } \\
\text { Orangtua }\end{array}$} & \multirow[b]{2}{*}{0} & \multirow[b]{2}{*}{$0 \%$} \\
\hline & 1 & $<20$ Tahun & & \\
\hline & 2 & $\begin{array}{l}20-35 \\
\text { Tahun }\end{array}$ & 21 & $81 \%$ \\
\hline & 3 & $\begin{array}{l}36-50 \\
\text { Tahun }\end{array}$ & 5 & $19 \%$ \\
\hline & 4 & $>50$ Tahun & 0 & $0 \%$ \\
\hline \multirow[t]{5}{*}{5} & \multicolumn{2}{|c|}{ Umur Anak } & & \\
\hline & 1 & 4 Tahun & 0 & $0 \%$ \\
\hline & 2 & 5 Tahun & 6 & $23 \%$ \\
\hline & 3 & 6 Tahun & 16 & $62 \%$ \\
\hline & 4 & $>6$ Tahun & 4 & $15 \%$ \\
\hline \multirow[t]{6}{*}{6} & \multicolumn{2}{|c|}{$\begin{array}{c}\text { Hubungan } \\
\text { dengan Anak }\end{array}$} & & \\
\hline & 1 & Ayah & 0 & $0 \%$ \\
\hline & 2 & Ibu & 26 & $100 \%$ \\
\hline & 3 & Kakek & 0 & $0 \%$ \\
\hline & 4 & Nenek & 0 & $0 \%$ \\
\hline & 5 & $\begin{array}{l}\text { Anggota } \\
\text { Keluarga } \\
\text { yang lain }\end{array}$ & 0 & $0 \%$ \\
\hline \multirow[t]{5}{*}{7} & \multicolumn{2}{|c|}{ Jumlah Anak } & & \\
\hline & 1 & $\begin{array}{c}1 \\
\text { bersaudar } \\
\text { a }\end{array}$ & 3 & $12 \%$ \\
\hline & 2 & $\begin{array}{c}2 \\
\text { bersaudar } \\
\mathrm{a} \\
\end{array}$ & 19 & $73 \%$ \\
\hline & 3 & $\begin{array}{c} \\
\text { bersaudar } \\
\text { a }\end{array}$ & 3 & $12 \%$ \\
\hline & 4 & $\begin{array}{c}>3 \\
\text { bersaudar } \\
\text { a }\end{array}$ & 1 & $4 \%$ \\
\hline \multirow[t]{5}{*}{8} & & endidikan & & \\
\hline & 1 & $\mathrm{SD}$ & 2 & $8 \%$ \\
\hline & 2 & SMP & 6 & $23 \%$ \\
\hline & 3 & SMA & 10 & $38 \%$ \\
\hline & 4 & $\begin{array}{l}\text { Akademik } \\
\text { /PT }\end{array}$ & 8 & $31 \%$ \\
\hline 9 & \multicolumn{2}{|c|}{ Pendapatan } & & \\
\hline & 1 & $\begin{array}{l}<\text { Rp. } 500 \\
\text { Ribu }\end{array}$ & 0 & $0 \%$ \\
\hline
\end{tabular}

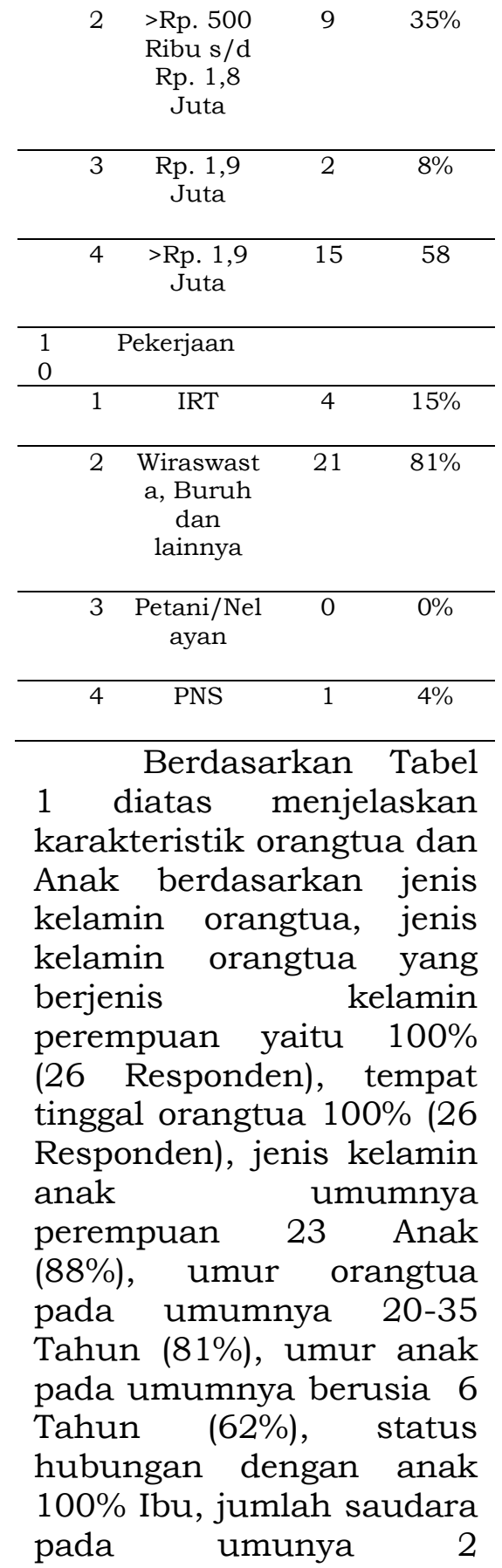


bersaudara

$(73 \%)$

pendidikan orangtua SMA (38\%) dan PT (31\%), pendapatan orangtua lebih dari 1,9 juta (58\%) dan pekerjaan orangtua Wiraswasta sejumlah (81\%).

$\begin{array}{cr}\text { Tabel 2: } & \text { rerata } \\ \text { pengetahuan } & \text { orangtua }\end{array}$ sebelum dan sesudah pemberian edukasi dengan poster tentang tentang pemberian nutrisi dalam pencegahan stunting di TK Bina Anaprasa Nurul Jadid

\begin{tabular}{|l|l|c|}
\hline \multirow{2}{*}{ Variable } & \multicolumn{2}{|c|}{ Perlakuan } \\
\cline { 2 - 3 } & $\begin{array}{l}\text { Rerata } \\
\text { (Means) }\end{array}$ & SD \\
\hline $\begin{array}{l}\text { Pengetahuan } \\
\text { orang tua } \\
\text { pemberian } \\
\text { nutrisi } \\
\text { sebelum } \\
\text { edukasi } \\
\text { poster }\end{array}$ & & 5,332 \\
\hline $\begin{array}{l}\text { Pengetahuan } \\
\text { orang tua } \\
\text { pemberian } \\
\text { nutrisi } \\
\text { setelah } \\
\text { edukasi } \\
\text { poster }\end{array}$ & 87,4 & \\
\hline
\end{tabular}

Rata-rata

penegtahuan orangtua sebelum dan sesudah pemebrian edukasi dengan poster tentang pemberian nutria pada anak.

Berdasarakan hasil analisis univariat pada kelompok perlakuan (pre dan post) didapatkan perbedaan means pre tes 52,1 SD 5,332 dan means post test 87,4 SD 12,351 dengan selisih rata-rata pengetahuan 7,019. Hal ini menunjukkan bahwa terdapat perbedaan selisih rata-rata pengetahuan sebelum perlakuan dengan sesudah perlakuan dengan metode pemberian edukasi poster. Peningkatan pendidikan seseorang, berdampak pada penambahan pengetahuan,

keterampilan. Sehingga kualitas perawatan disebabkan adanya kemampuan dari individu, kemampuan tersebut terbentuk dari pengetahuan,

keterampilan, perilaku dan pengalaman untuk melakukan perawatan berkualitas (Siagian, 2014). Menurut

(Muzaham, 1995) bahwa orang tidak akan mencari pertolongan medis bila mereka mempunyai pengetahuan dan motivasi minimal relevan dengan kesehatan, bila mereka memandang keadaan tidak cukup berbahaya, bila tidak yakin terhadap 
keberhasilan suatu

perawatan meskipun intervensi medis dan bila mereka melihat adanya beberapa kesulitan dalam melaksanakan perilaku kesehatan yang disarankan. Hal ini sejalan dengan (Azwar, 2001) motivasi adalah dorongan untuk melakukan yang positif bagi dirinya dan orang lain.

$$
\text { Penelitian (Rahayu, }
$$

2011; Rendy, 2013) mengungkapkan bahwa terdapat hubungan antara pendapatan keluarga dengan kejadian penyakit kronik bagi anggota keluarganya, pendapatan keluarga sangat berpengaruh terhadap kemampuan anak dalam mencari pendidikan baik formal maupun nonformal. Berdasarkan hal tersebut orangtua yang mempunyai pendapatan lebih baik, maka keluarga lebih mampu dalam menjaga kualitas perawatannya serta anak lebih dalam memproteksi diri dari bahaya dunia luar.

\begin{tabular}{lr}
\multicolumn{3}{c}{ Peningkatan } \\
pendapatan & orangtua \\
tidak & memberikan \\
pengaruh yang & signifikan \\
terhadap & kualitas
\end{tabular}
orangtua sudah dilalui motivasi orangtua. Hal itu disebabkan adanya ketidakmampuan orangtua dalam menerima informasi dari keluarga terdekat dan tenaga medis untuk dilakukan pengobatan medis. Pendapatan yang baik akan cenderung membuat orangtua untuk melakukan pengobatan alternatif yang terlebih dahulu. Orangtua yang mudah menerima informasi dari lingkungan akan membuat lebih mudah mempercayai pengobatan non medis. Meningkatnya pendapatan orangtua akan lebih leluasa orangtua mencari pengobatan tanpa harus memikirkan pengeluaran untuk pengobatan, meskipun pengobatan itu dilakukan dengan cara non-medis.

Penelitian

(Mariyam, 2008; Nanik Suryani, 2006) mengungkapkan status pekerjaan orangtua berpengaruh terhadap kemandirian serta motivasi anak dalam kegiatan sehari-hari. Berdasarkan hal tersebut 
individu yang mempunyai pekerjaan lebih mapan akan berdampak pada kemandirian anak dan motivasi melakukan kegiatan rutinitas.

Tingkat keberhasilan orangtua yang bekerja sebagai Ibu Rumah Tangga akan selaras dengan yang diinginkan bila adanya support yang baik dari orangterdekatnya. Namun, bila tidak ada support yang baik dari keluarga dan tenaga medis perawatan yang berkualitas yang diberikan oleh orangtua tidak akan terjadi.

Di Era modern ada perubahan peningkatan kebutuhan hidup keluarga, yang menyebabkan orangtua (Ibu) mencoba untuk ikut berperan dalam memenuhi kebutuhan ekonomi. Dampak dari itu semua adalah terjadinya peningkatan yang cukup signifikan tentang perempuan yang bekerja baik diperkantoran, karya jasa, kerya kerajinan dan pegawai kasar. Namun demikian pada kenyataan karena sibuk bekerja atau berkarir mengakibatkan perhatian terhadap keluarga berkurang, bahkan tidak sedikit yang akhirnya tidak memperhatikan kondisi anak (Gunarsa, 2004). Pekerjaan orangtua berdampak pada kuantitas dan kualitas perhatian orangtua terhadap anak. Menurut (Davis, Keith dan Newstrom, 2004) keterlibatan mental dan emosi orangtua akan mempengaruhi

keberhasilan dalam memberikan kualitas perawatan.

Informasi tentang kesehatan pada ibu hamil khususnya mengenai stunting dan pola pemberian nutrisi selama kehamilan juga dipengaruhi oleh akses informasi yang tersedia. Jarak antara tempat tinggal ke pelayanan kesehatan sebagai pemberi informasi perlu diperhatikan. Berdasarkan hasil survey bahwa jarak antara Puskesmas Rambah ke Desa sekitar 6 $\mathrm{km}$ namun dengan adanya bidan desa dan beberapa kader aktif dapat meningkatkan

pemahaman ibu hamil tentang kesehatannya. Berdasarkan hasil 
penelitian rata - rata ibu hamil memeriksakan kehamilannya sebanyak 2 - 3 kali selama kehamilan saat ini.

\section{Daftar Pustaka}

Bishwakarma, R., \& Vanneman, R. D. (2011). (2011). Bishwakarma, R., \& Vanneman, $R$. D. (2011). Spatial inequality in child nutrition: Implications of regional context and individual/household composition. Disertasi University of Maryland, College Park, 119-140.

Branca. (n.d.). de Onis, M., \& Branca, F. (2016). Childhood stunting: $A$ global perspective. Maternal and Child Nutrition.

https://doi.org/https://d oi.org/10.1111/mcn.122 31

Dewey, K. G. (2016, M. 1). (2016). Dewey, K. G. (2016, May 1). Reducing stunting by improving maternal, infant and young child nutrition in regions such as South Asia: Evidence, challenges and opportunities. Maternal and Child Nutrition, Vol. 12, pp. 27-38. https://doi.org/https://d oi.org/10.1111/mcn.122 82

Fitri, L. (2018). (n.d.). Fitri, L. (2018). Hubungan Bblr Dan Asi Ekslusif Dengan Kejadian Stunting Di Puskesmas Lima Puluh Pekanbaru. Jurnal Endurance, 3(1), 131. https://doi.org/https://d oi.org/10.22216/jen.v3i1 .1767

García Cruz, L. M., González Azpeitia, G., Reyes Súarez, D., Santana Rodríguez, A., Loro Ferrer, J. F., \& SerraMajem, L. (2017). (2017). García Cruz, L. M., González Azpeitia, G., Reyes Súarez, D., Santana Rodríguez, A., Loro Ferrer, J. F., \& Serra-Majem, L. (2017). Factors associated with stunting among children 
aged 0 to 59 months from the central region of Mozambique. Nutrients, $\quad$ 9(5). https://doi.org/https://d oi.org/10.3390/nu90504 91

Jakarta 12950, 2018. (2018). Kemenkes RI, "Profil Kesehatan 2018," Kementerian Kesehatan Republik Indonesia.,.

Jakarta, 2017. (2017). TNPPK, "Dalam 100 Kabupaten / Kota Prioritas Untuk Intervensi Anak Kerdil (Stunting),."

Kemenkes. (2018). Buletin Stunting. Kementerian Kesehatan Republik Indonesia301(5).

Kementerian Desa

Transmigrasi

Pembangunan Daerah Tertinggal dan. (2017). (n.d.). Kementerian Desa Transmigrasi

Pembangunan Daerah Tertinggal dan. (2017). Buku saku desa dalam penanganan stunting.
Buku Saku Desa Dalam Penanganan Stunting, 2-13.

Kementerian Kesehatan RI. (2018). (n.d.). Kementerian Kesehatan RI. (2018). Hasil Utama Riset Kesehatan Dasar. Kementrian Kesehatan ,Republik Indonesia, 1100.

https://doi.org/https://d oi.org/1 Desember 2013

Kementerian Koordinator Bidang Pembangunan Manusia dan Kebudayaan. (2018). (n.d.). Kementerian Koordinator Bidang Pembangunan Manusia dan Kebudayaan. (2018). Strategi Nasional Percepatan Pencegahan Anak Kerdil (STUNTING) Periode 2018-2024.

Kurnia Illahi, R. (2017). (n.d.). Kurnia Illahi, R. (2017). Hubungan Pendapatan Keluarga, Berat Lahir dan Panjang Lahir dengan Kejadian Stunting Balita 24 - 59 
BUlan di Bangkalan. 3(1), 1-14.

Media Gizi Indonesia, 1, 1319. (n.d.). Nadhiroh, Siti Rahayu; Ni'mah, $K$. (2010). Faktor yang berhubungan dengan kejadian.

Media Gizi Pangan, 25. (n.d.). Sukmawati, D. (2018). Status Gizi Ibu Saat Hamil, Berat Badan Lahir Bayi Dengan Stunting Pada Balita.

Menteri Kesehatan RI. (2016). (n.d.). Menteri Kesehatan RI. (2016). Pemenkes. Permenkes No. 39 Tahun 2016, 3(1). https://doi.org/https://d oi.org/https://doi.org/10 .3929/ethz-b-000238666

Munir, Z., Kholisotin, K., \& Hasanah, A. M. (2021). Faktor-Faktor Yang Berhubungan Dengan Peningkatan Kasus Stunting Pada Balita Di Kabupaten Probolinggo. Jurnal Keperawatan Profesional, 9(1), 47-69. https://doi.org/10.3365

0/jkp.v9i1.2037

Paudel, R., Pradhan, B., Wagle, R. R., Pahari, D. P., \& Onta, S. R. (2012). (n.d.). Paudel, R., Pradhan, B., Wagle, $R$. R., Pahari, D. P., \& Onta, S. R. (2012). Risk factors for stunting among children: A community based case control study in Nepal. Kathmandu University Medical Journal, 10(39), 18-24. https://doi.org/https://d oi.org/10.3126/kumj.v10 i3.8012

Picanyol, C. (2014). (2014). Is There a better way to track nutrition spending? In Global nutrition report 2014: Actions and accountability to accelerate the world's progress on nutrition. https://doi.org/http://eb rary.ifpri.org/utils/getfile /collection/p15738coll2/ id/128484/filename/128 695.pdf\%0Ahttp://dx.doi .org/10.7910/DVN/2785 7 
Probolinggo, 2019. (2019). BPS,

"Kabupaten

Probolinggo Dalam Angka,."

Probolinggo, 2020. (2020). H.

Supriyatno, "Kabupaten probolinggo Angka Stunting Tergolong Tinggi." Dinas Kesehatan Kab Probolinggo,.

Semarang: JKAKJ, 2018. (2018). D. A. . Intan G. P, Penerapan Aplikasi Berbasis Android Status Gizi Balita Terhadap Pengetahuan Ibu Dalam Pemantauan Status Gizi Anak Usia 12-24 Bulan, 2nd ed.

Surabaya, 2018. (2018). R. Jatim, "Hasil Utama Riskesdas 2018 Provinsi Jawa Timur,."

Udayana Mengabdi, vol. 15, no. 01,2016 . (n.d.). $N$. W. . U. I. M. . A. K.T. Adhi, "Pemberdayaan Desa dan Tokoh Masyarakat dalam Implementasi Strategi Deteksi Dini Kasus
Malnutrisi Anak di Desa Bukit Karangasem,."

WHO 2015. (n.d.). Stunting in a nutshell.

Bishwakarma, R., \& Vanneman, R. D. (2011). (2011). Bishwakarma, R., \& Vanneman, $R$. D. (2011). Spatial inequality in child nutrition: Implications of regional context and individual/household composition. Disertasi University of Maryland, College Park, 119-140.

Branca. (n.d.). de Onis, M., \& Branca, F. (2016). Childhood stunting: $A$ global perspective. Maternal and Child Nutrition. https://doi.org/https://d oi.org/10.1111/mcn.122 31

Dewey, K. G. (2016, M. 1). (2016). Dewey, K. G. (2016, May 1). Reducing stunting by improving maternal, infant and young child nutrition in 
regions such as South Asia: Evidence, challenges and opportunities. Maternal and Child Nutrition, Vol. 12, pp. 27-38. https://doi.org/https://d oi.org/10.1111/mcn.122 82

Fitri, L. (2018). (n.d.). Fitri, L. (2018). Hubungan Bblr Dan Asi Ekslusif Dengan Kejadian Stunting Di Puskesmas Lima Puluh Pekanbaru. Jurnal Endurance, 3(1), 131. https://doi.org/https://d oi.org/10.22216/jen.v3i1 .1767

García Cruz, L. M., González Azpeitia, G., Reyes Súarez, D., Santana Rodríguez, A., Loro Ferrer, J. F., \& SerraMajem, L. (2017). (2017). García Cruz, L. M., González Azpeitia, G., Reyes Súarez, D., Santana Rodríguez, A., Loro Ferrer, J. F., \& Serra-Majem, L. (2017). Factors associated with stunting among children aged 0 to 59 months from the central region of Mozambique. Nutrients, $\quad 9(5)$. https://doi.org/https://d oi.org/10.3390/nu90504 91

Jakarta 12950, 2018. (2018). Kemenkes RI, "Profil Kesehatan 2018," Kementerian Kesehatan Republik Indonesia., .

Jakarta, 2017. (2017). TNPPK, "Dalam 100 Kabupaten / Kota Prioritas Untuk Intervensi Anak Kerdil (Stunting),."

Kemenkes. (2018). Buletin Stunting. Kementerian Kesehatan Republik Indonesia301(5).

Kementerian Desa Transmigrasi

Pembangunan Daerah Tertinggal dan. (2017). (n.d.). Kementerian Desa Transmigrasi

Pembangunan Daerah Tertinggal dan. (2017). Buku saku desa dalam penanganan stunting. 
Buku Saku Desa Dalam

Penanganan Stunting, 2-13.

Kementerian Kesehatan RI. (2018). (n.d.). Kementerian Kesehatan RI. (2018). Hasil Utama Riset Kesehatan Dasar. Kementrian Kesehatan ,Republik Indonesia, 1100.

https://doi.org/https://d oi.org/1 Desember 2013

Kementerian Koordinator Bidang Pembangunan Manusia dan Kebudayaan. (2018). (n.d.). Kementerian Koordinator Bidang Pembangunan Manusia dan Kebudayaan. (2018). Strategi Nasional Percepatan Pencegahan Anak Kerdil (STUNTING) Periode 2018-2024.

Kurnia Illahi, R. (2017). (n.d.). Kurnia Illahi, R. (2017). Hubungan Pendapatan Keluarga, Berat Lahir dan Panjang Lahir dengan Kejadian Stunting Balita 24 - 59
BUlan di Bangkalan. 3(1), 1-14.

Media Gizi Indonesia, 1, 1319. (n.d.). Nadhiroh, Siti Rahayu; Ni'mah, $K$. (2010). Faktor yang berhubungan dengan kejadian.

Media Gizi Pangan, 25. (n.d.). Sukmawati, D. (2018). Status Gizi Ibu Saat Hamil, Berat Badan Lahir Bayi Dengan Stunting Pada Balita.

Menteri Kesehatan RI. (2016). (n.d.). Menteri Kesehatan RI. (2016). Pemenkes. Permenkes No. 39 Tahun 2016, 3(1). https://doi.org/https://d oi.org/https://doi.org/10 .3929/ethz-b-000238666

Munir, Z., Kholisotin, K., \& Hasanah, A. M. (2021). Faktor-Faktor Yang Berhubungan Dengan Peningkatan Kasus Stunting Pada Balita Di Kabupaten Probolinggo. Jurnal Keperawatan Profesional, 9(1), 47-69. 
https://doi.org/10.3365 0/jkp.v9i1.2037

Paudel, R., Pradhan, B., Wagle, R. R., Pahari, D. P., \& Onta, S. R. (2012). (n.d.). Paudel, R., Pradhan, B., Wagle, $R$. R., Pahari, D. P., \& Onta, S. R. (2012). Risk factors for stunting among children: A community based case control study in Nepal. Kathmandu University Medical Journal, 10(39), 18-24. https://doi.org/https://d oi.org/10.3126/kumj.v10 i3.8012

Picanyol, C. (2014). (2014). Is There a better way to track nutrition spending? In Global nutrition report 2014: Actions and accountability to accelerate the world's progress on nutrition. https://doi.org/http://eb rary.ifpri.org/utils/getfile /collection/p15738coll2/ id/128484/filename/128 695.pdf\%0Ahttp://dx.doi .org/10.7910/DVN/2785 7
Probolinggo, 2019. (2019). BPS, "Kabupaten Probolinggo Dalam Angka,."

Probolinggo, 2020. (2020). $\mathrm{H}$. Supriyatno, "Kabupaten probolinggo Angka Stunting Tergolong Tinggi." Dinas Kesehatan Kab Probolinggo,.

Semarang: JKAKJ, 2018. (2018). D. A. . Intan G. P, Penerapan Aplikasi Berbasis Android Status Gizi Balita Terhadap Pengetahuan Ibu Dalam Pemantauan Status Gizi Anak Usia 12-24 Bulan, 2nd ed.

Surabaya, 2018. (2018). $R$. Jatim, "Hasil Utama Riskesdas 2018 Provinsi Jawa Timur,."

Udayana Mengabdi, vol. 15, no. 01, 2016. (n.d.). N. W. . U. I. M. . A. K.T. Adhi, "Pemberdayaan Desa dan Tokoh Masyarakat dalam Implementasi Strategi Deteksi Dini Kasus 
Zainal Munir: Pencegahan Stunting

Malnutrisi Anak di Desa Bukit Karangasem,."

WHO 2015. (n.d.). Stunting in a nutshell. 